\title{
Expression of voltage-gated sodium channel in primary tumors and corresponding metastases in the Copenhagen rat model of prostate cancer
}

\author{
Prostat kanseri Copenhagen sıçan modelinin primer tümörleri ve metastazlarında voltaj kapılı \\ sodyum kanal ekspresyonu
}

Şenay Yıldırım

\begin{abstract}
Objective: Increasing evidence indicates that prostate cancer (PCa) cells possess voltage-gated sodium channels (VGSCs) and these channels contribute to the metastatic progression of the disease. In the present study, it was aimed to investigate the heterotopic expression of VGSCs in carcinogenesis and metastasis. It was evaluated whether the expression of VGSC in strongly metastatic rat Mat-LyLu PCa cells observed in vitro is also conserved when these cells form primary tumors and metastasize to the lungs upon their subcutaneous injection in rats.
\end{abstract}

Methods: PCa model was induced in male Copenhagen rats by subcutaneous implantation of strongly metastatic Mat-LyLu cells. The expression of VGSCs was studied in the model utilizing molecular biological and immunochemical techniques.

Results: Reverse transcription PCR and immunohistochemistry showed that the expression of VGSC is conserved in the primary prostate tumors of Mat-LyLu and not eliminated in the corresponding lung metastases at both the mRNA and protein level.

Conclusion: The results are consistent with the predominant role of VGSC in the metastatic progression of $\mathrm{PCa}$ and consistently support the VGSC hypothesis of cancer progression. J Clin Exp Invest 2013; 4 (4): 422-428

Key words: Prostate cancer, voltage-gated sodium channel, primary tumor, metastasis

\section{INTRODUCTION}

Prostate cancer $(\mathrm{PCa})$ is one of the most frequent malignancies in men. The major problem arising from PCa is its propensity to metastasize. Androgen deprivation therapy, which causes initial regression, is the cornerstone of metastatic PCa treatment due to the androgen dependent nature of $\mathrm{PCa}$ cells.

\section{ÖZET}

Amaç: Artan miktardaki kanıt prostat kanser (PCa) hücrelerinin voltaj kapılı sodyum kanalları (VGSCs)'na sahip olduğunu ve bu kanalların hastalığın metastatik ilerlemesine katkıda bulunduğunu göstermektedir. Mevcut çalışmada, VGSC'lerin karsigonezde ve metastazdaki heterotopik ekspresyonunu araştırmak amaçlanmıştır. Güçlü metastatik sıçan Mat-LyLu PCa hücrelerinde in vitro olarak gözlemlenen VGSC ekspresyonunun, bu hücrelerin sıçanlara subkuten enjekte edildiğinde primer tümör oluştuğunda ve hücreler akciğerlere metastaz yaptığında korunup korunmadığı, değerlendirilmiştir.

Yöntemler: PCa modeli Copenhagen ırkı erkek sıçanlarda güçlü metastatik Mat-LyLu hücrelerinin subkuten implantasyonu ile oluşturulmuştur. VGSC eksprsyonu bu modelde moleküler biyolojik ve immünokimyasal yöntemlerle araştırıımıştır.

Bulgular: Ters transkripsiyon PCR ve immünohistokimya yöntemleri VGSC ekspresyonunun Mat-LyLu primer prostat tümörlerinde korunduğunu ve akciğer metatsazlarında da bu ekspresyonun devam ettiğini, mRNA ve protein düzeyinde göstermiştir.

Sonuç: Sonuçlar, VGSC'lerin PCa'nin metastatik ilerlemesindeki baskın rolü ile uyumludur ve 'kanserin ilerlemesinde VGSC'lerin rolü' hipotezini tutarlı bir şekilde desteklemektedir.

Anahtar kelimeler: Prostat kanseri, voltaj-kapılı sodyum kanalı, primer tümör, metastaz

Very frequently however, androgen-independent cancers emerge and almost all tumors progress to the lethal stage of the disease [1]. Therefore, an understanding of the metastatic mechanisms in $\mathrm{PCa}$ is important to the development of novel therapies.

Currently, there is a considerable body of evidence emphasizing the importance of voltage-gated sodium channels (VGSCs) in the progression of 
PCa. This evidence has previously described the presence of VGSCs in strongly metastatic rat MatLyLu [2] and human PC-3 [3] PCa cell lines using electrophysiological and molecular methods [4,5]. It has been shown that these cells specifically overexpress the Nav1.7 subtype of VGSCs [4]. VGSC expression has also been reported in clinical $\mathrm{PCa}$ specimens [6] and Nav1.7 mRNA and protein levels are significantly upregulated in the prostatic tissues of PCa patients compared to non-PCa prostate tissues [7]. VGSCs are also expressed in several other types of carcinoma including breast cancer $[8,9]$, small cell lung cancer [10], non-small lung cancer [11], melanoma [12], glioma [13], mesothelioma [14], ovarian cancer [15], colon cancer [16] and cervical cancer [17]. Importantly, the expression of VGSC has been shown to contribute to the metastasis of these carcinomas by enhancing a number of metastatic cell functions in vitro such as invasion $[9,16,18,19]$, directional motility $[20,21]$, metastatic cell morphology [22], endocytosis $[9,10,23]$ and detachment [24]. It is clear from these studies that a variety of VGSC isoforms are functional in different cancer cell types. For example, while Nav1.7 seems to be essential for PCa metastatic behaviors $[5,25]$, the Nav1.5 subtype is critical for breast, ovarian and colon cancer invasiveness $[15,16,26]$. In the studies of clinical samples, it was shown that Nav1.5 expressions in primary breast and ovarian cancer specimens strongly correlate with the presence of lymph node metastasis $[9,15]$.

Metastasis, a complex-multistep process, requires complex experimental systems for its study and the modeling of this biological complexity is possible using animal models [27]. Recently, in the first in vivo experimental study, it was reported that the injection of low doses of tetrodotoxin (TTX), a specific VGSC blocker, into primary tumors significantly suppressed metastasis to lung and prolonged lifetime in the Mat-LyLu Copenhagen rat model of PCa [28]. However, it is unclear whether the VGSC expression is present in the metastatic lesions or whether clones, which do not express VGSC are responsible for the generation of metastases. The objective of this study was to evaluate the VGSC hypothesis of cancer progression by extending the in vivo approach to molecular studies. It was examined the expression status of VGSC in the strongly metastatic rat Mat-LyLu PCa cells, primary prostate tumors of Mat-LyLu and corresponding lung metastases. The results provided a substantial contribution to the in vivo evaluation of the hypothesis.

\section{METHODS}

\section{Cell Culture}

The strongly metastatic Mat-LyLu rat prostate cancer cell line was cultured at $37^{\circ} \mathrm{C}$ with $5 \% \mathrm{CO} 2$ in RPMI-1640 medium supplemented with $1 \%$ fetal bovine serum (FBS; Invitrogen/Gibco), $250 \mathrm{nM}$ dexamethasone (Sigma-Aldrich) and 2 mM L-glutamine (Invitrogen/Gibco) [25].

\section{Tumor implantation and dissection}

All animal procedures were carried out under the ethical rules of Istanbul University. Experiments were carried out on 2.5-month-old male Copenhagen rats weighing 200-220g (Charles River, Suizfeld, Germany). Mat-LyLu cells were freshly harvested and resuspended in fresh supplemented medium. To generate a PCa tumor model $2 \times 10^{5}$ tumor cells were implanted into the right flank of Copenhagen rats. Twenty days after tumor cell inoculation, the rats were euthanized with isoflurane. Primary tumors and lung metastases were quickly removed from the euthanized animals and specimens (free of necrotic material) were frozen in liquid nitrogen and stored at $-80^{\circ} \mathrm{C}$ for PCR and immunohistochemical studies. Portions of primary tumors and lung metastases were also fixed in $10 \%$ neutral buffered formaldehyde and embedded in paraffin blocks for histological evaluation and other immunohistochemical studies.

\section{Reverse transcription polymerase chain reaction (RT-PCR)}

Total RNA was extracted from the Mat-LyLu cells and frozen primary tumor and lung metastases tissues using TRIzol Reagent (Invitrogen) according to the manufacturer's specifications. The quantity and quality of the extracted RNA in the samples were determined with an ND-1000 Spectrophotometer (Labtech). One microgram of total RNA was used as the substrate for single-stranded cDNA synthesis using Superscript II reverse-transcriptase (Invitrogen) with random hexamer mix (Invitrogen). The PCR reactions were prepared using $5 \mu \mathrm{l}$ cDNA, each primer and TaqDNA polymerase (Qiagen) at a final volume of $20 \mu \mathrm{l}$. The reaction mixture was then subjected to PCR amplification for 35 cycles consisting of heat denaturation, annealing and extension $[4,7]$. Cytochrome b5 reductase (Cytb5R), which has been shown to remain unchanged in rat $\mathrm{PCa} 7$, was used to control for variables including sample-to-sample differences in the quality and 
quantity of the RNA and reverse-transcription efficiency. In each PCR reaction, controls without reverse transcriptase and without added cDNA were also performed. The Nav1.7 (the major VGSC $\alpha$ subtype in Mat-LyLu cells) primers were: 5'-TTCATGACCTTGAGCAACCC-3' (Forward) and 5'-TCTCTTCGAGTTCCTTCCTG-3' (Reverse); annealing temperature, $60^{\circ} \mathrm{C}$; and Cytb5R primers were: 5'-ACACGCATCCCAAGTTTCCA-3' (Forward) and 5'-CATCTCCTCATTCACGAAGC-3' (Reverse); annealing temperature, $60^{\circ} \mathrm{C} .4,7 \mathrm{PCR}$ products were then analyzed by electrophoresis in $1.5 \%$ agarose gel and visualized by UV trans-illumination (Uvitec).

\section{Immunocytochemistry}

The presence of VGSC protein in Mat-LyLu cells was examined by immunocytochemistry using an "anti-sodium channel" polyclonal antibody. This antibody (Upstate-Millipore, Cat no: 06-811) rose in rabbits against the highly conserved cytosolic linker region between domains III and IV (peptide sequence TEEQKKYYNAMKKLGSKKP, amino acids 1490-1508) of known VGSCs a-subunits. The cells were cultured for 48 hours on coverslips. The samples were fixed with $4 \%$ paraformaldehyde in PBS and then blocked with $10 \%$ normal swine serum (Vector). Endogenous biotin activity of the cells was blocked with an avidin biotin blocking kit (Vector). The cells were incubated for $60 \mathrm{~min}$ with the primary antibody (1:100 dilution, Upstate) in $10 \%$ serum/PBS. For negative controls, cells were treated without antibody. The Mat-LyLu cells were then incubated for 60 min in biotinylated secondary antibodies (1:125 dilution, Dako) and processed for avidin-peroxidase staining as described by the manufacturer (Vectastain Kit, Vector) with diaminobenzidine hydrochloride (DAB, Vector) as the chromogen. Coverslips were mounted on slides using Entellan.

\section{Immunohistochemistry}

VGSC protein expression was examined both in paraffin and frozen sections using standard immunohistochemical techniques. Paraffin sections of 4-5 $\mu \mathrm{m}$ thickness were deparaffinized with xylene and rehydrated through graded ethanol. Endogenous peroxidase was suppressed by incubation in $3 \% \mathrm{H}_{2} \mathrm{O}_{2}$. Antigen retrieveal was performed in a microwave oven in EDTA (pH 8.0) for at least $30 \mathrm{~min}$. The slides were incubated with $10 \%$ normal swine serum (Vector) in PBS, then with an "anti-sodium channel" primary antibody (1/100 dilution, Upstate) for $60 \mathrm{~min}$. The slices were incubated with biotinyl- ated secondary antibody (1:125 dilution, Dako) and processed using the avidin biotin-peroxidase system (Vectastain Kit, Vector). Antibody binding was visualized using DAB (Vector). For the immunodetection of the VGSCs in frozen sections, the same protocol described above was carried out except for the deparaffinization and antigen retrieval steps. In all immunostaining a negative (omission of primary antibody) control was used. Image analyses were performed using an Olympus camera mounted on an Olympus light microscope in conjunction with Olympus DP71 software.

\section{RESULTS}

\section{Histopathological observations on Mat- LyLu primary prostate tumors and the corresponding lung metastases}

Subcutaneous implantation of $2 \times 10^{5}$ Mat-LyLu PCa cells produced primary tumors. Metastases were observed in both the right and left side of the lungs in all animals. The smallest nodule was $\sim 0.1 \mathrm{~mm}$ in diameter and the largest was $\sim 1.5 \mathrm{~mm}$. Representative photomicrographs of the paraffin section of one of the primary tumors and corresponding lung metastasis are shown in Figure 1. In histological examinations, the primary prostate tumors revealed a cellular and nuclear polymorphism. The tumor cells showed a polygonal cell structure and large, round to oval nuclei usually with a single nucleolus (Figure $1 \mathrm{~A}, 1 \mathrm{~B}$ ). Histological evaluation of the lungs showed numerous unencapsulated metastases (Figure 1C). Metastatic nodules were composed of small clusters of round to irregularly shaped neoplastic cells and the cytological features of these lesions were generally similar to primary tumors (Figure 1D).

\section{VGSC mRNA expression in Mat-LyLu cells, Mat-LyLu primary prostate tumors and the corresponding lung metastases}

Conventional RT-PCR was used for the screening of Nav1.7 (the predominant subtype of VGSCs) expression in Mat-LyLu cells, Mat-LyLu primary prostate tumors and corresponding lung metastases (Figure 2). PCR studies confirmed that the MatLyLu cells expressed Nav1.7 mRNA. Nav1.7 mRNA expression was also detected in both the Mat-LyLu primary prostate tumor and corresponding lung metastases specimens of the animals. Cytb5R internal control amplification showed highly consistent expression across all samples (Figure 2). No bands were observed in negative reverse transcriptase and negative cDNA samples (data not shown). 

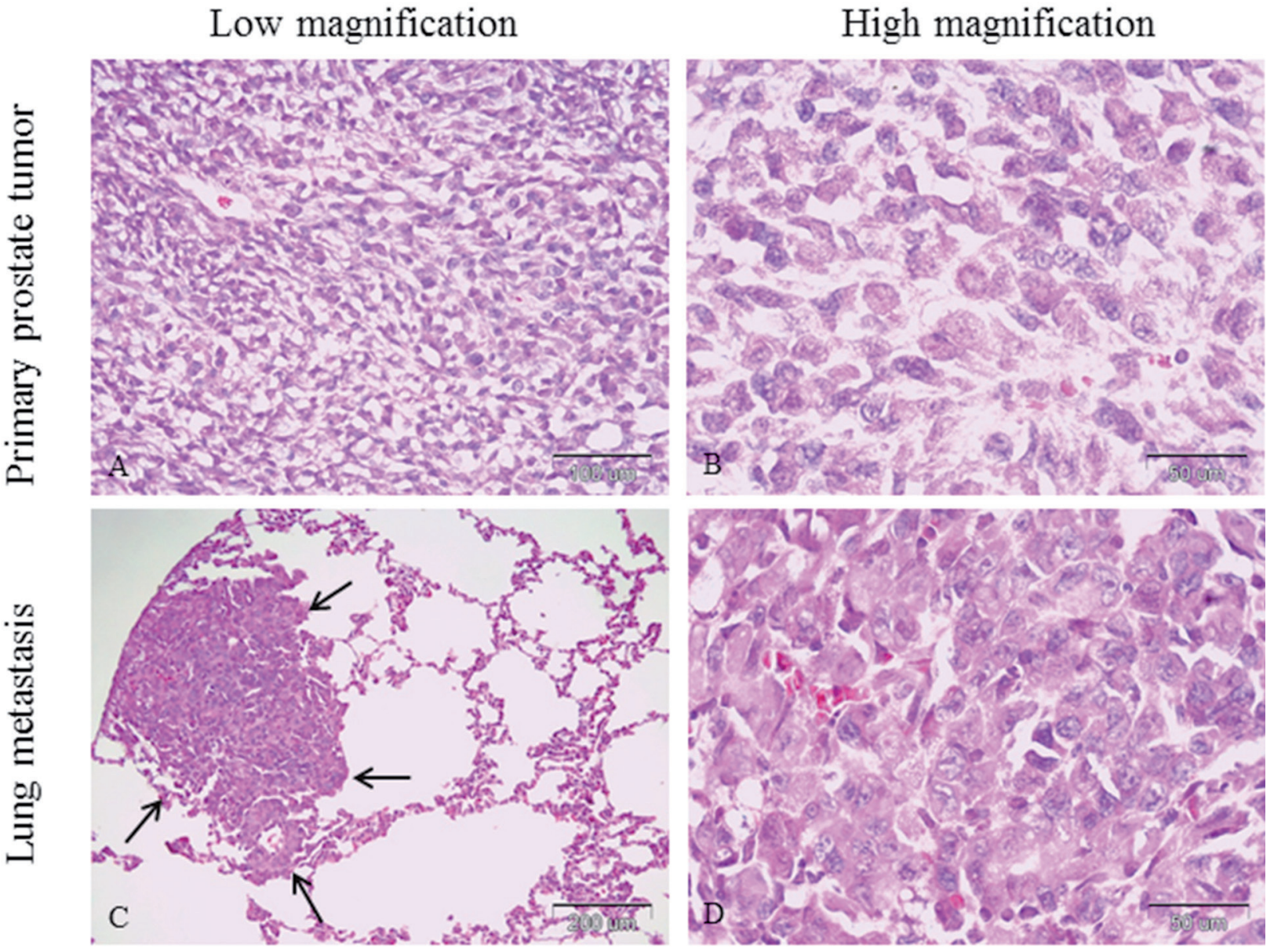

Figure 1.Photomicrographs of paraffin sections of a representative primary tumor and corresponding lung metastasis (hematoxylin and eosin staining). A: Primary tumor, low magnification, B: Primary tumor, high magnification, C: Lung metastasis, low magnification (arrows indicate metastatic lesion) and D: Lung metastasis, high magnification. Scale bars: $100 \mu \mathrm{m}(\mathrm{A}), 50 \mu \mathrm{m}(\mathrm{B}, \mathrm{D}), 200 \mu \mathrm{m}(\mathrm{C})$.

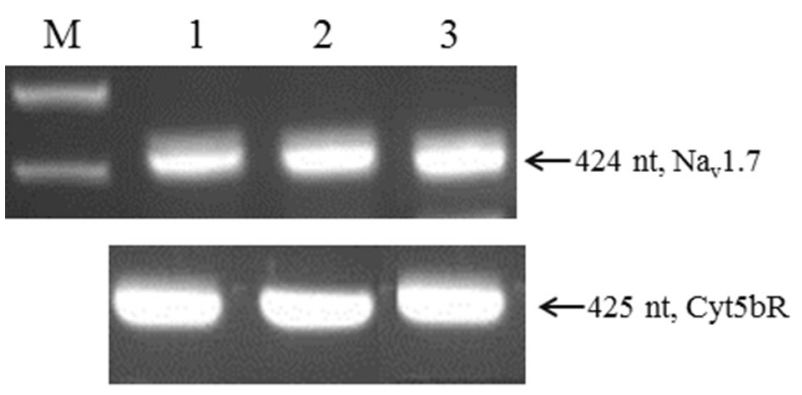

Figure 2. Voltage-gated sodium channel/Nav1.7 mRNA expression in Mat-LyLu cells, Mat-LyLu primary prostate tumor and the corresponding lung metastases. The electrophoresis results of Nav1.7 and cytochrome b5 reductase (Cyt5bR) RT-PCRs are shown. Lanes; M: DNA Ladder, 1: Mat-LyLu PCa cells, 2: Mat-LyLu primary prostate tumor, 3: Lung metastasis. Cytb5R internal control amplification showed highly consistent expression across all samples.
VGSC protein expression in Mat-LyLu cells, Mat-LyLu primary prostate tumors and the corresponding metastases.

Immunochemical staining demonstrated channel protein expression in Mat-LyLu cells (Figure $3 A)$. The VGSC protein localization was determined in the plasma membrane and cytosolic compartments of cells. No expression of VGSC protein was detected in negative controls without the antibody (Figure 3B).

Primary prostate tumors and corresponding metastases were assessed for VGSC protein expression by immunohistochemistry in both the paraffin and frozen sections. Immunohistochemical analyses showed that VGSC protein expression was present both in primary Mat-LyLu prostate tumors and the corresponding metastases (Figure 4). Tumor cells showed a positive diffuse staining pat- 
tern for VGSC. At high magnification there is a positive staining of the tumor cells in the regions of the cytoplasm surrounding the nucleus. This immunoreactivity most likely represents cytoplasmic stores of protein available for transport to the surface membrane and functional form of protein on the plasma membrane. In all primary tumor and lung metastasis (both small and large nodule) specimens exhibited VGSC positive staining and the obtained staining pattern was identical. Control sections (not shown) processed without primary antibody produced no staining.
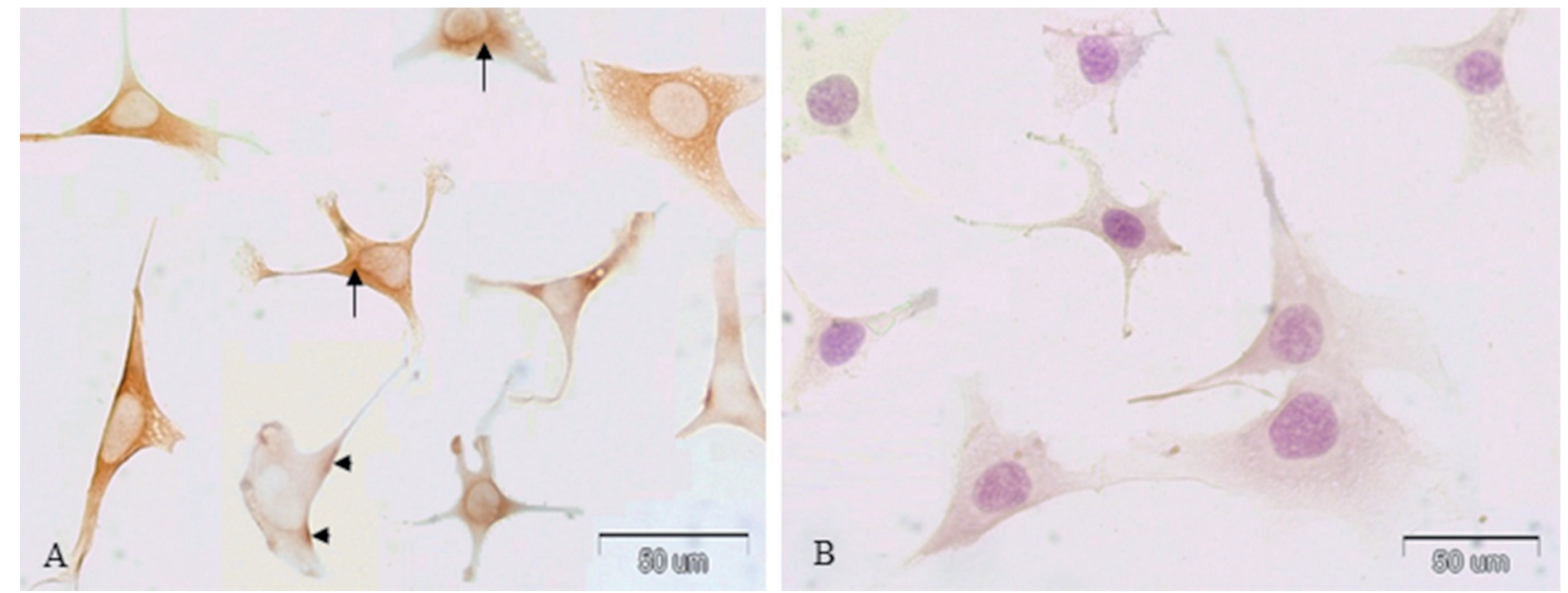

Figure 3. Immunocytochemical detection of voltage-gated sodium channel protein expression in cultured Mat-LyLu cells. A: Positive immunoreactivity of VGSC protein in Mat-LyLu cells. Membrane (arrowheads) and cytoplasmic (arrows) staining is indicated. B: Negative control (omission of the anti-Na+ channel antibody) cells counterstained with hematoxylin. Scale bars: $50 \mu \mathrm{m}$.

\section{A (Paraffin sections)}

\section{Low magnification}
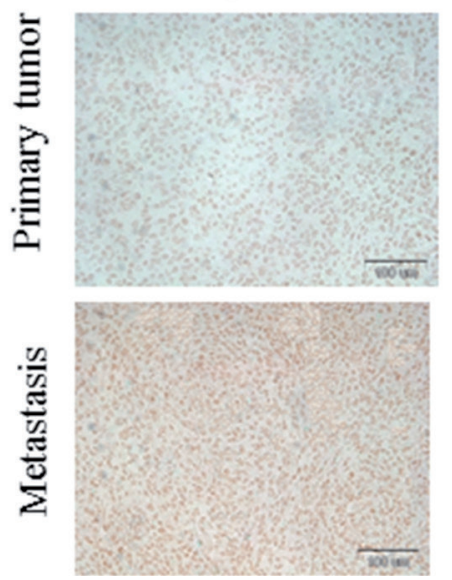

High magnification
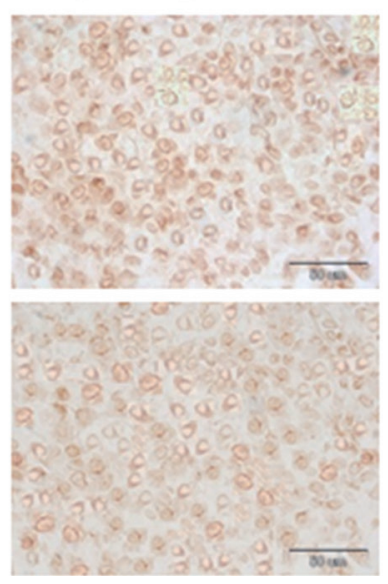

\section{B (Frozen sections)}

Low magnification

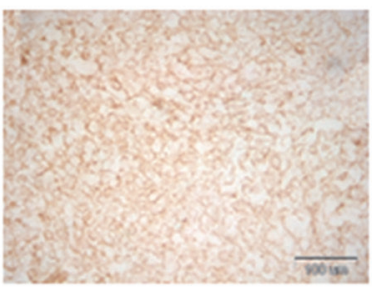

High magnification

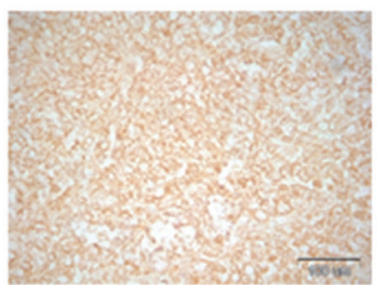

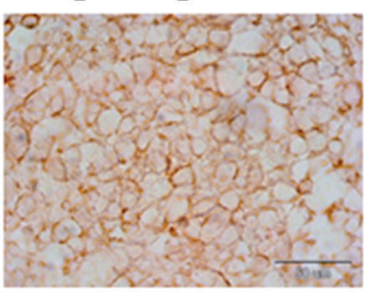

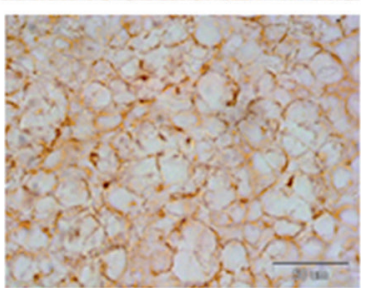

Figure 4. Representative immunostaining of VGSC protein expression in primary prostate tumors and paired lung metastases. A: Equal VGSC immunohistochemical pattern between primary tumor and paired metastasis. Sections were prepared from formalin-fixed paraffin-embedded tissue specimens. B: Equal VGSC immunohistochemical pattern between primary tumor and paired metastasis. Sections were prepared from fresh-frozen tissue specimens. No expression of VGSCs was detected in negative controls without the primary antibody (data not shown). Scale bars: $100 \mu \mathrm{m}$ in high magnification and $50 \mu \mathrm{m}$ in low magnification. 


\section{DISCUSSION}

Functional VGSC expression has been shown to potentiate metastatic potential by enhancing a range of in vitro metastatic cell behaviors, including directional motility $[9,20,21]$ and Matrigel invasion $[2,5,9]$. More recently, blocking VGSC activity in primary tumors was shown to suppress lung metastases in the Dunning Mat-LyLu prostate adenocarcinoma model of the Copenhagen rat [28]. This is the first demonstration of metastasis suppression in vivo by a highly specific VGSC blocker. In the present study, it was studied the expression status of VGSC in primary tumors and their corresponding metastases using this model. VGSC expression, which is observed in strongly metastatic Mat-LyLu $\mathrm{PCa}$ cells in vitro is also conserved when these cells form primary tumors and metastasize to the lungs upon their subcutaneous injection in rats. These results are consistent with the predominant role of VGSC in the metastatic progression of $\mathrm{PCa}[4,5,7]$.

In the present study the presence of VGSC in Mat-LyLu cells was confirmed by RT-PCR and immunocytochemistry at the mRNA and protein level. For tumor models generated from in vitro cell lines, it is important to confirm the presence of the relevant target in the growing tumors and not just in the cell lines from which they originated, because in vivo cultivation can alter target gene and protein expression through changes in the microenvironment [29]. The PCR measurements and immunohistochemical analyses confirmed expression of VGSC mRNA and protein in primary Mat-LyLu prostate tumors, consistent with the predominant role of VGSC in metastatic PCa. [5,7].

Some studies have shown that VGSC mRNA and/or protein expression occurred in biopsies of human PCa [6,7], breast cancer [9], ovarian cancer [15] and colon cancer [16]. It was also shown that VGSC expressions in primary breast and ovarian cancer specimens strongly correlate with the presence of lymph node metastasis $[9,15]$. However, it was not studied VGSC expression in metastatic lesions. This study demonstrated the existence of VGSC expression in metastatic site.

Metastasis continues to be the most significant problem in the treatment of $\mathrm{PCa}$ cancer. As with all cancer, metastatic activity is the main cause of death for PCa patients. An understanding of the molecular basis of metastasis and the development of anti-metastatic therapies enable reductions in patient morbidity and mortality [30]. Currently, the molecular basis of metastasis is relatively unknown. According to classical genetic selection hypothesis, a few rare cells within primary tumors acquire mutations over time which provides some advantages. The advantageous genetic alterations enable these cells to escape the primary tumor and form metastases at distant sites. However, more recent studies performed by DNA microarray analyses suggest that the acquisition of metastatic phenotype may happen relatively early during tumorigenesis ('ab initio'). This hypothesis is mainly based on the finding that several types of primary tumors harbor a geneexpression signature associated with metastases [31]. In the present study, we found that PCa metastases show VGSC expression as their primary tumor. In this respect, our results are consistent with the ab initio hypothesis. Actually, the two hypotheses are not mutually exclusive and an 'integrative view' has been proposed which contemplates the presence of metastasis 'initiation', 'progression' and 'virulence' genes [32]. Metastasis initiation genes are supposed to provide an advantage in the primary tumor and perform functions which enable the tumor cells to escape the primary tumor. According to this view, VGSC which underlies tumor cell invasion, motility, etc. $[2,9,25]$ seems to possess the characteristics of a metastasis initiation gene.

\section{ACKNOWLEDGEMENTS}

This study was supported by Scientific Research Project Coordination Unit of Istanbul University (Project number: 4343). The work of SY was supported by the Ömer Anıl Scholarship of Kanser Araştırma Vakfı (KAV, Turkish Republic of Northern Cyprus). I would like to thank Professor Mustafa B A Djamgoz (Imperial College, London) for his support with cells and animals.

\section{REFERENCES}

1. Fitzpatrick JM, Schulman C, Zlotta AR, Schröder FH. Prostate cancer: a serious disease suitable for prevention. BJU Int T 2009;103:864-870.

2. Grimes JA, Fraser SP, Stephens GJ, et al. Differential expression of voltage-activied $\mathrm{Na}+$ currents in two prostatic tomour cell lines: contribution to invasiveness in vitro. FEBS Letters 1995;369:290-294.

3. Laniado ME, Lalani EN, Fraser SP, et al. Expression and functional analysis of voltage-activated $\mathrm{Na}+$ channels in human prostate cancer cell lines and their contrubition to invasion in vitro. Am J Pathol 1997;150:1213-1221.

4. Diss JK, Archer SN, Hirano J, et al. Expression profiles voltage gated $\mathrm{Na}+$ channel alpha-subunit genes in rat and human prostate cancer cell lines. Prostate 2001;48:165-178. 
5. Nakajima T, Kubota N, Tsutsumi T, et al. Eicosapentaenoic acid inhibits voltage-gated sodium channels and invasiveness in prostate cancer cells. $\mathrm{Br} \mathrm{J}$ Pharmacol 2009;156:420-431.

6. Abdul M, Hoosein N. Voltage-gated sodium ion channels in prostate cancer: expression and activity. Anticancer Research 2002;22:1727-1730.

7. Diss JK, Stewart D, Pani F, et al. A potential novel marker for human prostate cancer: Voltage-gated sodium channel expression in vivo. Prostate Cancer \& Prostatic Diseases 2005;8:266-273.

8. Roger S, Besson P, Guennec J. Involvement of a novel fast inward sodium current in the invasion capacity of a breast cancer cell line. Biochimica et Biophysica Acta 2003;1616:107-111.

9. Fraser SP, Diss JKJ, Chioni A-M, et al. Voltage-gated sodium channel expression and potentiation of human breast cancer metastasis. Clinical Cancer Research 2005;11:5381-5389.

10. Onganer PU, Djamgoz MBA. Small-cell lung cancer (human): Potentiation of endocytic membrane activity by voltage gated $\mathrm{Na}+$ channel expression in vitro. Journal of Membrane Biology 2005;204:67-75.

11. Roger S, Rollin J, Barascu A, et al. Voltage-gated sodium channels potentiate the invasive capacities of human non-small-cell lung cancer cell lines. International Journal of Biochemistry \& Cell Biology 2007;39:774-786.

12. Allen DH, Lepple-Wienhues A, Cahalan MD. Ion channel phenotype of melanoma cell lines. J Membrane Biol 1997;155:27-34.

13. Schrey M, Codina C, Kraft R, et al. Molecular characterization of voltage-gated sodium channels in human gliomas. Neuroreport 2002;20;13:2493-2498.

14. Fulgenzi G, Graciotti L, Faronato M, et al. Human neoplastic mesothelial cells express voltage-gated sodium channels involved in cell motility. The International Journal of Biochemistry \& Cell Biology 2006;38:1146-1159.

15. Gao R, Shen Y, Cai J, et al. Expression of voltage-gated sodium channel subunit in human ovarian cancer. Oncology Reports 2010;23:1293-1299.

16. House CD, Vaske CD, Schwartz AM, et al. Voltagegated $\mathrm{Na}+$ channel SCN5A is a key regulator of a gene transcriptional network that controls colon cancer inavasion. Cancer Res 2010;70:6957-6967.

17. Hernandez-Plata E, Ortiz CS, Marquina-Castillo B, et al. Over expression of Nav1.6 channels is associated with the invasion capacity of human cervical cancer. Inter J Cancer 2011;Doi:10.1002/ijc.26210.

18. Bennett ES, Smith BA, Harper JM. Voltage-gated $\mathrm{Na}+$ channels confer invasive properties on human prostate cancer cells. Pflugers Arch - Eur Physiol 2004;447:908-914.
19. Gillet L, Roger S, Besson P, et al. Voltage-gated sodium channel activity promotes cysteine cathepsindependent invasiveness and colony growth of human cancer cells. J. Biol. Chem 2009;284:8680-8691.

20. Djamgoz MBA, Mycielska M, Madeja Z, et al. Directional movement of rat prostate cancer cells in directcurrent electric field: involvement of voltage-gated $\mathrm{Na}+$ channel activity. J Cell Sci 2001;114:2697-2705.

21. Fraser SP, Salvador V, Manning E, et al. Contribution of functional voltage-gated $\mathrm{Na}+$ channel expression to cell behaviours involved in the metastic cascade in rat prostate cancer: I. Lateral motility. J Cell Physiol 2003;169:479-487.

22. Fraser SP, Ding Y, Liu A, et al. Tetrodotoxin suppresses morphological enhancement of the metastic Mat-LyLu rat prostate cancer cell line. Cell Tissue Res 1999;295:505-512.

23. Krasowska M, Grzywna ZJ, Mycielska ME, Djamgoz MBA. Patterning of endocytotic vesicles and its control by voltage-gated $\mathrm{Na}+$ channel activity in rat prostate cancer cells: fractal analyses. Eur Biophys J 2004;33:535-542.

24. Palmer CP, Mycielska ME, Burcu $H$, et al. Single cell adhesion measuring apparatus (SCAMA): application to cancer cell lines of different metastatic potential and voltage-gated $\mathrm{Na}+$ channel expression. Eur Biophysics J 2008;37:359-368.

25. Brackenbury W, Djamgoz MBA. Activity-dependent regulation of voltage-gated $\mathrm{Na}+$ channel expression in Mat-LyLu rat prostate cancer cell line. J Physiology 2006;573:343-356.

26. Brackenbury WJ, Chioni AM, Diss JKJ, Djamgoz MBA. The neonatal splice variant of Nav1.5 potentiates in vitro metastatic behaviour of MDA-MB-231 human breast cancer cells. Breast Cancer Res Treat 2007;101:149-160.

27. Khanna C, Hunter K. Modelling metastasis in vivo. Carcinogenesis 2005;26:513-523.

28. Yildirim S, Altun S, Gumushan $\mathrm{H}$, et al. Voltage-gated sodium channel activity promotes prostate cancer metastasis in vivo. Cancer Letters 2012;323:58-61.

29. Hollingshead MG. Antitumor efficacy testing in rodents. J Natl Cancer Inst 2008;100:1500-1510.

30. Steeg PS, Theodorescu D. Metastasis: a therapeutic target for cancer. Nat Clin Pract Oncol 2008;5:206219.

31. Hunter KW, Crawford NP, Alsarraj JJ. Mechanisms of metastasis. Breast Cancer Res 2008;10:1:S2.

32. Nguyen DX, Massague J. Genetic determinants of cancer metastasis. Nature Reviews Genetics 2007;8:341-352. 